\title{
Modulation of disease severity in cystic fibrosis transmembrane conductance regulator deficient mice by a secondary genetic factor
}

Richard Rozmahel, Michael Wilschanski, Angabin Matin. Suzanne Plyte, Mary Oliver, Wojtek Auerbach, Aideen Moore, Janet Forstner, Peter Durie, Joseph Nadeau,

Christine Bear \& Lap-chee Tsui

Nature Genetics 12, 280-287 (1996)

The Southern blot in Fig. $1 b$ (shown right) was inadvertantly omitted. Also, "The Canadian Genetic Diseases Network" should have been included as part of the acknowledgement to "the Canadian Network of Centers of Excellence".

$b$, Autoradiographs show the results of Southern blot hybridization screening of ES cell clones containing a correctly targeted gene locus. Three correctly targeted cell lines $(7 \mathrm{c} 2,8 \mathrm{c} 2$ and $10 \mathrm{~d} 6)$ correspond to lanes showing a hybridizing 4.9-kb BamHI fragment in each panel, respectively. The 6.0-kb fragment represents the endogenous (unaltered) genomic sequence. From 211 double resistant clones screened, seven showed the presence of a $4.9-\mathrm{kb}$ band, indicating the desired modification. The ES cell lines $7 \mathrm{c} 2$, $8 \mathrm{c} 2$ and $10 \mathrm{~d} 6$ which demonstrated the $4.9-\mathrm{kb}$ band were expanded and used to produce chimaeric mice by aggregation with CD1 morulae ${ }^{28}$. The cell line $7 \mathrm{c} 2$ resulted in

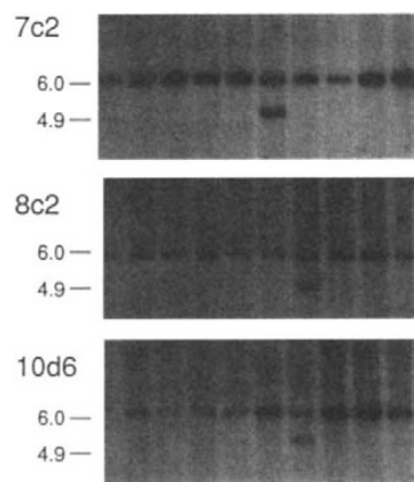

the production of two chimaeric male mice designated as $7 \mathrm{c} 2 \mathrm{a}$ and $7 \mathrm{c} 2 \mathrm{~b}$ which were approximately 20 and $100 \%$ ES derived, respectively. The chimaera $7 \mathrm{c} 2 \mathrm{a}$ did not result in germ-line transmission of the ES genome, but the $7 \mathrm{c} 2 \mathrm{~b}$ chimaera transmitted the $129 /$ Sv genome to $100 \%$ of its offspring.

\section{Schizophrenia susceptibility and chromosome 6p24-22}

Hugh Gurling, Gursharan Kalsi, Andrew Chih-Hui Chen, Melanie Green, Robert Butler, Tim Read, Patrice Murphy, David Curtis \& Tonmoy Sharma

Nature Genetics 11, 234-235 (1995)

Dr. Andrew Chih-Hui Chen's name was misspelled as Andrew Hui-Sui Chen.

\section{Mutation of the gene in a family with optic nerve colobomas, renal anomolies and vesicoureteral reflux}

Phaikasame Sanyanusin, Lisa A. Schimmenti, Leslie A. McNoe, Teresa A. Ward, Mary Ella M. Pierpont, Michael J. Sullivan, William B. Dobyns \& Michael R. Eccles

Nature Genetics 9, 358-364 (1995)

The primers specified for exon 4 are incorrect. The correct sequences are: Forward: 5'-TGG AGC TGC GTT TCC TGC CTT-3' Reverse: 5'-AAT TGG CCG GAA TAG GAG TGG-3'

Also, the second to last sentence should read: "Sporadic and autosomal dominant optic nerve colobomas are relatively common in the population." 